Research Article

\title{
Characteristics of mothers and stunting toddlers in Pekuncen Village, Wiradesa, Pekalongan, Indonesia
}

\author{
Siti Rofiqoh ${ }^{1^{*}}$, Imam Hanifudin Rizkian ${ }^{1}$, Naila Vandawi $^{1}$, Febri Lianasari ${ }^{1}$ \\ ${ }^{1}$ Faculty of Health Science, Universitas Muhammadiyah Pekajangan Pekalongan, \\ Pekalongan, Indonesia.
}

*Correspondence: rofiqoh.siti@yahoo.com. Telp: +6281542030114

Received 05 May, 2020; Accepted 28 May, 2020; Published 28 May, 2020

\begin{abstract}
Background: Stunting is the condition of short stature due to abnormal growth caused by a severe malnutrition problem that needs attention. Stunting can cause health problems, decrease productivity, and trigger poverty in the future. This study aims to determine the characteristics of mothers and stunting toddlers in Pekuncen village Wiradesa Pekalongan District, Central Java, Indonesia.

Methods: The study was conducted in Pekuncen village in the Wiradesa subdistrict of the Pekalongan District. The retrospective design was used in this study. Respondent was recruited using total sampling techniques. A set of questionnaires was employed to collect the data among 35 respondents, which is the mothers of stunting toddler.
\end{abstract}

Results: The results showed most of the respondents $(82.7 \%)$ hold basic education level. $77.1 \%$ of respondents have family income < regional minimum salary of Pekalongan District. More than half of respondents $(68.6 \%)$ have less nutrition knowledge. No mothers have good nutrition knowledge. Less than half $(42.9 \%)$ provide parenting democratic type of feeding, and there are still $14.3 \%$ of mothers giving the neglect parenting feeding type. While the characteristics of stunting toddlers are $68.6 \%$ female, $37.1 \%$ aged $3-4$ years, $28.6 \%$ aged $1-3$ years, $42.9 \%$ do not get exclusive breastfeeding, and $88.6 \%$ have a history of normal born weight.

Conclusions: Stunting toddler in Pekuncen village Wiradesa, Pekalongan was associated with a parent who has elementary education, family income less than the Regional Minimum Salary. Most of them have less nutrition knowledge level, and almost half of them provide parenting with the democratic type of feeding. While the characteristics of stunting toddlers were the majority of women, and nearly half do not get exclusive breastfeeding, and most have a normal birth weight history. We suggest that related parties should collaborate to reduce stunting prevalence based on the characteristics of mothers and stunting toddlers.

Keywords: Mother, Toddlers, Stunting, Pekalongan.

\section{INTRODUCTION}

Stunting is a condition of failure to thrive in toddlers due to chronic malnutrition so that the children become too short compared to their ages (1). Stunting is based on body length index compared to age (PB/U) or height compared to age (TB/U) with a limit (z-score) of less than 2 SD (2). Stunting in toddlers is one of the problems in the world, including Indonesia. The incidence of stunting in the world in 2017 reached $22.2 \%$ or around 150.8 million children (3). 


\section{Epidemiology and Society Health Review $\mid \mathbf{E S H R}$}

The prevalence of stunting in Indonesia ranks fifth largest in the world (1). In 2018, the prevalence of stunting in Indonesia was quite high, reaching $30.8 \%$ and in Central Java Province in the year 2014 amounted to $22.57 \%$ (4). Based on the data from the Pekalongan District Health Office in 2017, the Wiradesa subdistrict of Pekalongan District has the highest number of stunting cases. Data from the Wiradesa Health Center in Pekalongan DIstrict shows that there are 3,556 children, and 386 are stunted. The highest number of stunting toddlers' cases is at Pekuncen village in Wiradesa. Pekalongan (5).

Stunting is caused by multidimensional factors such as poor parenting practices, limited quality health services, lack of family access to nutritious food, and access to clean water and sanitation (1). Parenting practices include maternal knowledge about nutrition and children's food intake, including exclusive breastfeeding and infant treatment with low birth weight. The incorrect feeding behavior by the parent causing the lack of nutritional intake received by toddlers. A mother's education is also related to the ability to care for children properly. Family income factors cause a lack of family access to nutritious food. Family income closely related to the family's ability to provide nutritious food and access to health services required for the growth of toddlers.

Stunting is a problem that needs serious attention because if left untreated, it will cause an impact on adulthood. Various issues arise in stunting children, including issues of stunted physical growth, mental development, health problems, poor school performance, low education, and low income as adults that have an impact on poverty (1). So, it is necessary to identify the factors that trigger off stunting, especially in areas with a high prevalence of stunting. It will be useful for decision-makers on providing appropriate intervention and policy to solve stunting. This study aims to describe the characteristics of mothers and stunting toddlers in Pekuncen village Wiradesa subdistrict of the Pekalongan District.

\section{METHODS}

\section{Study design}

The research design is quantitative with a retrospective approach. Mother and stunting toddlers data has obtained from Wiradesa public health center, Pekalongan. Door to door visit was conducted to interview the respondent.

\section{Setting}

The research took place in Pekuncen village Wiradesa subdistricts of the Pekalongan District with the highest case of stunting toddlers in 2017.

\section{Data source and data collection}

A questionnaire was used to collect the data. Parenting questionnaire regarding infant feeding was adopted from Astuti about the Parenting Feeding Style (6). The questionnaire consisted of 24 questions divided into 17 questions of demandingness (D) and seven questions of responsiveness $(R)$. Questionnaire answers using a Likert scale consisting of 5 alternative answers, namely, 0) never, 1) rarely, 2) sometimes, 3) often, 4) always. This questionnaire has been tested for validity and reliability with Pearson's correlation point demandingness results of Cronbach's alpha value of 0.85 and Cronbach alpha of responsiveness of 0.82 . Thus this questionnaire was declared reliable (6). The nutritional knowledge questionnaire consisted of 18 questions. It had been tested for validity and reliability, with $r$ count $>0.44$ and Cronbach alpha also $>0.44$, so they were valid and reliable.

Parenting feeding, because of the abnormal data distribution, then categorized into democratic parenting, if the $D$ and $R \geq$ median; Authoritarian parenting, if $D \geq$ median and $R<$ median; 
Permissive parenting, if $D<$ median and $R \geq$ median and neglect parenting, if $D$ and $R<$ median. While knowledge is categorized as good if the value is $76-100$, enough, if $56-75$ and less if 0-55.

\section{Sample population}

This study's population was the mothers of stunting toddlers in Pekuncen village Wiradesa subdistrict of the Pekalongan District. We applied total sampling to select the respondent. Accordingly, this study involved 35 respondents. The criteria for the participant were mothers of stunting toddlers who were domiciled in the selected village and willing to participate in this study. In contrast, the exclusion criteria were toddlers who are not cared for by mothers.

\section{Variables}

The variables of this study include the characteristics of mothers and stunting toddlers. Maternal characteristics include the level of education, knowledge about nutrition, family income, and parenting feeding. Toddler characteristics include age, sex, history of exclusive breastfeeding, and history of Low Birth Weight.

\section{Analysis}

The analysis was performed using descriptive and percentage analysis.

\section{RESULTS}

\section{Characteristics of Mothers in Stunting Toddlers}

The characteristics of mothers in stunting toddlers, which include the mother's education, family income, mother's knowledge about nutrition, and parenting feeding for a toddler, are presented in Tables 1.

Table 1. Characteristics of Mothers in Stunting Toddlers $(n=35)$

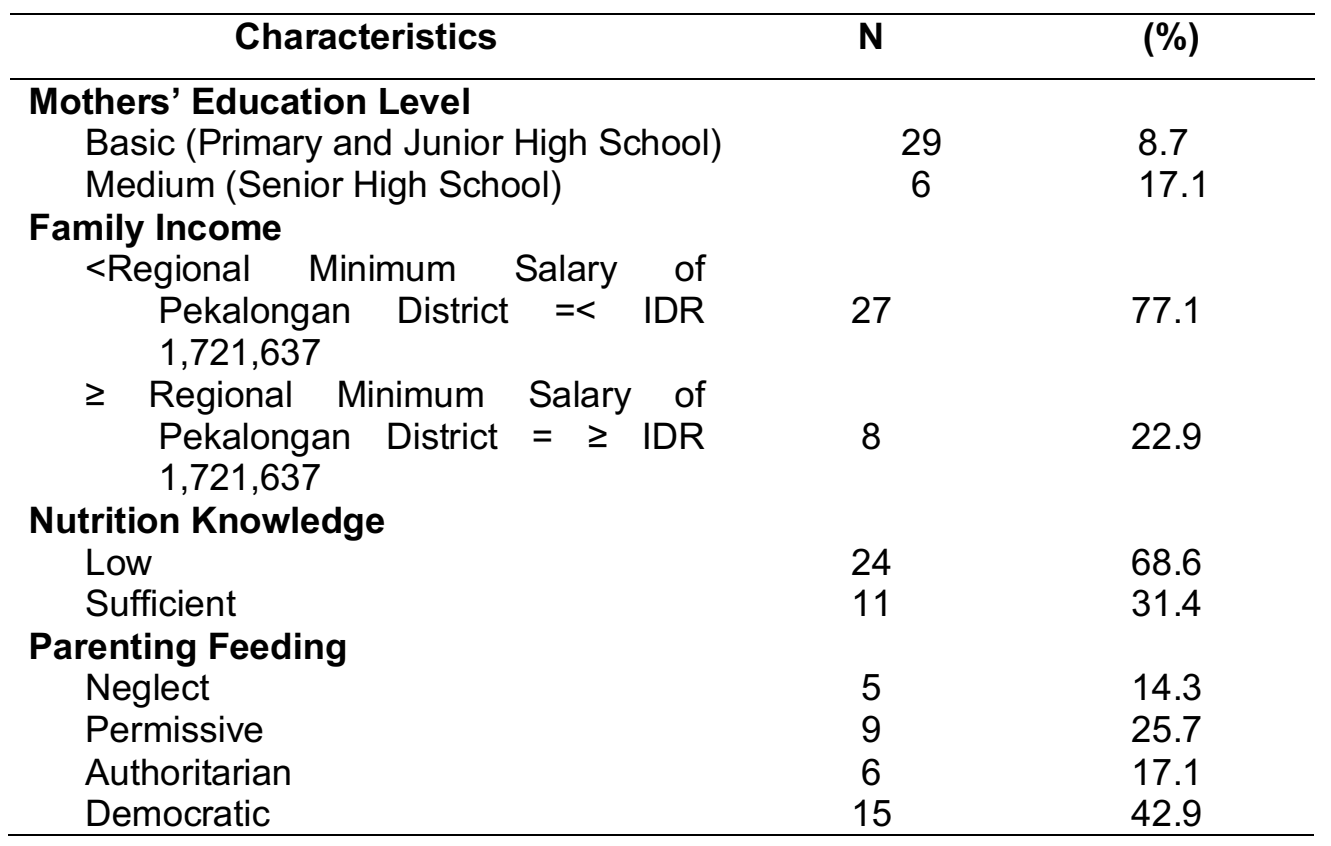

Table 1 shows that most mothers' education level 29 (82.7\%) hold basic education level, only $6(17.1 \%)$ have middle education level, and none of the respondents have a high education 


\section{Epidemiology and Society Health Review $\mid \boldsymbol{E S H \boldsymbol { R }}$}

level (University). Most of the $27(77.1 \%)$ have family income less than the regional minimum salary of Pekalongan District. Knowledge about nutrition is mostly less than $24(68.6 \%)$, and none of them has sufficient knowledge, parenting feeding practices most of the $15(42.9 \%)$ were democratic, $9(25.7 \%)$ permissive, and there is still $5(14.3 \%)$ neglect.

\section{Characteristics of Stunting Toddlers}

The characteristics of stunting toddlers, which include gender, age, history of breastfeeding, and birth weight history, are illustrated in Tables 2 .

Table 2. Characteristics of Stunting Toddlers $(n=35)$

\begin{tabular}{lcc}
\hline \multicolumn{1}{c}{ Characteristics } & N & $\%$ \\
\hline $\begin{array}{l}\text { Gender } \\
\text { Male }\end{array}$ & 11 & 31.4 \\
Female & 24 & 68.6 \\
Age & & \\
1-2 year & 10 & 28.6 \\
2-3 year & 9 & 25.7 \\
3-4 year & 13 & 37.1 \\
4-5 year & 3 & 8.6 \\
Breastfeed History & & \\
$\quad$ Exclusive Breastfeed & 20 & 57.1 \\
$\quad$ In exclusive Breastfeed & 15 & 42.9 \\
Birthweight History & & \\
$\quad$ Normal & 31 & 88.6 \\
$\quad$ Low & 4 & 11.4 \\
\hline
\end{tabular}

Table 2 shows that most of the toddlers are female (24 (68.6\%), more than one third 13 $(37.1 \%)$ aged $3-4$ years old, and $10(28.6 \%)$ are $1-2$ years old. Almost half of the toddlers did not receive exclusive breastfeeding; there are about $15(42.9 \%)$ and only four toddlers $(11.4 \%)$ with a history of low birth weight.

\section{DISCUSSIONS}

The characteristics education of mothers with stunting toddlers shown the majority of them hold basic education level. Highly educated people are more likely to adopt healthy lifestyles, maintain personal fitness, consume nutritious food, avoid things that damage health (7). Likewise, mothers with higher education are more likely to take care of their children properly. High educated mothers are more capable of implementing a healthy lifestyle to their children, maintaining their children's fitness, providing and feeding nutritious food to their children. They are also capable of protecting their children from things that can interfere with health. These abilities are needed by children so that children can grow and develop properly. Research conducted by Setiawan, Mahmud, and Masrul (2018) in Padang and Anisa (2012) in Depok, stated that mother's education was related to the incidence of stunting in children. Mothers with higher education have a lower risk of stunting $(8,9)$. Mothers with higher education can formulate strategies to maintain the continuity of better child care, be able to solve problems properly, such as providing proper food to children, bringing children to health services, etc. Therefore, increasing the mother's education level is important for reducing stunting (10). In 


\section{Epidemiology and Society Health Review $\mid \mathbf{E S H R}$}

contrast to mothers with lower education are at greater risk of the incidence of stunting. Mothers with low education are less able to take good care of their children. As a result, the need for nutrition and health among children at risk is not sufficient. These conditions, if it prolonged, will cause stunting in children.

Income factor is also one of the causes of stunting. The results of the study in Table 1 shows that most mothers of stunted toddler earn less than the regional minimum salary. Research in Padang shows that the level of family income is related to stunting toddlers (8). Income relates to access to nutritious food, access to health services, and children's education that have a positive impact on the nutritional status of children (11). Good family income supports the ability of families to provide nutritious food to their families, including toddlers. Nutritious food is needed by children to maintain the health of the child's body, the child's growth, and the development process. Likewise, good family income is needed for the fulfillment of health services that are needed to ensure the health status of families and children. A good family income is also needed to access good education services for children so that children are facilitated into a healthy and smart generation. Conversely, low-income families cause the inability to meet family needs. Families are unable to provide nutritious and varied food so that the child's nutrition intake is reduced. Poor nutrition for a long time is one of the factors causing stunting. Health services can also be inaccessible to low-income family members. Poor nutrition is at risk of decreasing the child's immune system. Children are more likely to get sick more often if access to health services still not proper. This condition worsens the nutritional status of children who can be more at risk of experiencing malnutrition and stunting.

The results showed the majority of mothers about nutrition knowledge is very low. Meanwhile, knowledge is a fundamental domain for the formation of one's actions (12). The lack of nutrition knowledge about mothers causes an inability to serve and feed good, nutritious food. Thus, the nutrient intake in children will be disrupted. Chronic disruption of nutrient intake in a toddler can be at risk of causing stunting.

The characteristics of mothers regarding parenting for child feeding in Table 1 show that most are democratic, some are permissive and authoritarian, but some are neglectful. $17.1 \%$ in this study, the mother gives parenting feeding authoritarian type. Authoritarian parenting is parenting by parents who tend to force, rule, and punish children always to follow parental orders without reason. Children with this parenting style tend to the trouble to express his wish and high levels of depression. Permissive parenting is parenting as opposed to authoritarian parenting, in permissive parenting parents give freedom to children to do anything, parents are very concerned with the needs of children's feelings, but parents tend to spoil children. The risk of stunting can occur in the permissive type of parenting if the child chooses to consume less nutritious foods, while parents tend to fulfill the child's wishes. Parenting neglect is the worst because it cannot provide control but cannot provide warmth to the children (13). In this type, food that enters the child's body is controlled by the children because of a lack of control, demands, and direction from parents. Less nutritious feeding food will inhibit the toddler's growth so that a risk of stunting (14). Democratic parenting is ideal parenting among others because, in this parenting, children live within the provisions that must be met, but they also get attention and fulfillment of adequate needs (13). The results of this study indicate the characteristics of parenting feeding of mothers in stunting toddlers are mostly democratic type. However, if parents continue to apply the democratic type to the condition of children who behave to avoid certain foods for long periods, they can be at risk of malnutrition (stunting) 


\section{Epidemiology and Society Health Review $\mid \boldsymbol{E S H \boldsymbol { R }}$}

$(15,16)$. In the democratic parenting type, if the parent's knowledge about nutrition is less well, also risk causing nutritional problems in children (17). Parents need to implement parenting feeding the most appropriate to the child's condition. In daily life, parents can provide appropriate parenting multidimensional child's condition. Although parents parenting feeding implement democratic type, in certain situations, parents need to be authoritarian if the increasing demands of a child to eat are considered effective in maintaining normal nutrition. Instead, permissive parenting is required if the child is considered to require a more pleasant dining atmosphere to maintain a normal nutritional status (6).

The characteristics of stunting toddlers in the results of the study in Table 2 show that almost half of the toddlers do not get exclusive breastfeeding. Breast milk is the best for infants, and exclusive breastfeeding should be given in the first six months. This means that the baby is only given breast milk without other additional other than medicines, vitamins, and minerals according to the doctor's instructions. Giving exclusive breastfeeding to infants up to six months old will increase the child's immunity and maintain the child (18). Research by Hindawati and Rusdiati (2018) in Jember and Setiawan, et al. (2018) in Padang shows that exclusive breastfeeding is not associated with stunting $(8,19)$. This can occur because stunting is indeed caused by multi factors, not only exclusive breastfeeding but complementary feeding factors. After six months of infancy, adequate and varied nutritious feeding in children also greatly determines the nutritional status of children. The number of feeding problems occurs in children after six months, and even toddlers are at risk of reduced nutrient intake in children. If parents have less knowledge and are less concerned about the problem, then the children are at risk of a lack of additional food intake that can have an impact on the incidence of stunting in toddlers. Likewise, the history of low birth weight in Table 2 shows that only four toddlers $(11.4 \%)$ reported low birth weight, while $(78.6 \%)$ reported normal birth weight. This also shows that stunting is not only caused by a history of low birth weight, but there are still many other factors, including nutritional intake after birth, also affect the incidence. Septira and Anggraini's research results (2016) in Lampung show that proper nutrition early on could help prevent growth disorders in infants with low birth weight (LBW) (20). Providing adequate nutrition early on infants with low birth weight will pursue infant growth, so the infant experiences normal growth.

\section{CONCLUSIONS}

This research concluded that the characteristics of mothers of stunting toddlers in Pekuncen village Wiradesa, Pekalongan are $82.7 \%$ of basic education level, $77.1 \%$ of family income < regional minimum salary in Pekalongan District, $68.6 \%$ have less nutrition knowledge level, $31.4 \%$ had sufficient nutrition knowledge. There are no mothers who have adequate nutrition knowledge, and $42.9 \%$ provided parenting with the democratic type of feeding. In comparison, $14.3 \%$ of mothers give neglect parenting type, $25.7 \%$ of mothers gave care pattern of permissive feeding, and 17.1 authoritarian type. While the characteristics of stunting toddlers are $68.6 \%$ female, $37.1 \%$ aged $3-4$ years, $28.6 \%$ aged $1-3$ years, $42.9 \%$ do not get exclusive breastfeeding, and $88.6 \%$ have a history of normal birth weight. 


\section{Epidemiology and Society Health Review $\mid \mathbf{E S H R}$}

\section{Authors' contribution}

IHR, NV, and FL contributed to licensing and the data collection, SR contributed to the data analysis, report writing and manuscript publication.

\section{Funding}

This research has not received external funding

\section{Conflict of interest}

There is no conflict of interest in this research.

\section{REFERENCES}

1. Tim Nasional Percepatan Penanggulangan Kemiskinan (TNPPK). 100 Kabupaten/Kota Prioritas untuk Intervensi Anak Kerdil (stunting). JakartaTNPPK. 2017;1.

2. Yudianti \& Rahmat Haji Saeni. Pola Asuh Dengan Kejadian Stunting Pada Balita Di Kabupaten Polewali Mandar. J Kesehat Manarang Jur Gizi Poltekes Kemenkes Mamuju. 2016;2(1):21-5.

3. Kementrian Kesehatan Republik Indonesia (KEMENKES RI). Bulletin Jendela Data Dan Informasi: Situasi Balita Pendek (Stunting) di Indonesia. Available from: httpp//www.pusdatin.kemenkes.go.id. 2018;

4. Riskesdas. Laporan riset kesehatan dasar. Jakarta Badan Penelit dan Pengemb Kesehatan kementrian Kesehat RI. 2018;

5. Dinas Kesehatan Kabupaten Pekalongan. Profil Kesehatan Kabupaten Pekalongan 2017. Pekalongan Dinas Kesehatan Kabupaten Pekalongan. 2018;

6. Yumni DZ. Perbedaan Pola Asuh Pemberian Makan dan Perilaku Makan Antara Balita Obesitas dan Balita Tidak Obesitas di Kota Semarang. Skripsi SGz, Univ Diponegoro Semarang Nutr Coll Vol 6, Nomor 1 Tahun 2017 [Internet]. 2016;43. Available from: http://ejournal-s1.undip.ac.id/index.php/jnc

7. Huang W. Understanding the Effects of Education on Health : Evidence from China. 2015; Available from: https://scholar.harvard.edu/ weihuang/publications/understandingeffectseducation-health-evidence-china

8. Setiawan E, Machmud R. Artikel Penelitian Faktor-Faktor yang Berhubungan dengan Kejadian Stunting pada Anak Usia 24-59 Bulan di Wilayah Kerja Puskesmas Andalas Kecamatan Padang Timur Kota Padang Tahun 2018. 2018;7(2):275-84. Available from: http://jurnal.fk.unand.ac.id

9. Anisa P. Faktor-Faktor Yang Berhubungan Dengan Kejadian Stunting Pada Balita Usia 25-60 Bulan Di Kelurahan Kalibiru Depok Tahun 2012. Jakarta Univ Indones. 2012;

10. Senbanjo IO, Oshikoya KA, Odusanya OO, Njokanma OF. Prevalence of and Risk factors for Stunting among School Children and Adolescents in Abeokuta, Southwest Nigeria. J Heal Popul Nutr [Internet]. 2011;29(4):364-70. Available from: www.bioline.org

11. Bishwakarma R. Spatial inequality in child nutritionin Nepal: Implications ofregional contextand individual household compotition (Disertasi). Univ Maryland Proquest informationand Learn Co. 2011;

12. Notoatmodjo S. IImu perilaku manusia. Jakarta: Rineka Cipta; 2012.

13. Baskoro D. Menjadi Lebih Baik (Parenting Healing). Jakarta: PT Alex Media; 2019.

14. Rambu, N. Pola Asuh Pemberian Makan pada balita Stunting Usia 6-12 bulan di Kabupaten Sumba Tengah Nusa Tenggara Timur. Journal of Nutrition College, 2017;6(1):84-95

15. Menzel, J. Avoidant-Restrictive Food Intake Disorder (ARFID). Neda Feeding Hope.2016. 


\section{Epidemiology and Society Health Review $\mid \boldsymbol{E S H R}$}

Available from: https://www.nationaleatingdisorders.org/avoidant-restrictive-food-intakedisorder-arfid

16. Ehmke, R. More Than Picky Eating. Kids With a Serious A Version to Many Foods May Need Help to Overcome Avoidance. 2016. Available from: http://childmind.org/article/more-than-picky-eating/

17. Manuaba. Obesitas Jangan Dianggap Remeh. 2004. Available from: www.smallcrab.com

18. Perry, S.E, Hockenberry, M.J., Loedermilk, D.L., Wilson DL. Maternal child nursing care. Missouri: Mosby Elsevier. 2010;

19. Hindrawati, N. \& R. Gambaran riwayat pemberian ASI eksklusif dengan kejadian stunting pada anak usia 6-24 bulan di Desa Arjasa Kecamatan Arjasa Kabupaten Jember. JKAKJ. 2018;2(1):1-7.

20. Septira, S. \& Angraini, D.I. Nutrisi bagi Bayi Berat Badan Lahir Rendah (BBLR) untuk Mengoptimalkan Tumbuh Kembang. 2016. Available from: http://repository.lppm.unila.ac.id/2020/1/Salsabila\%26Dian_september\%202016.pdf 